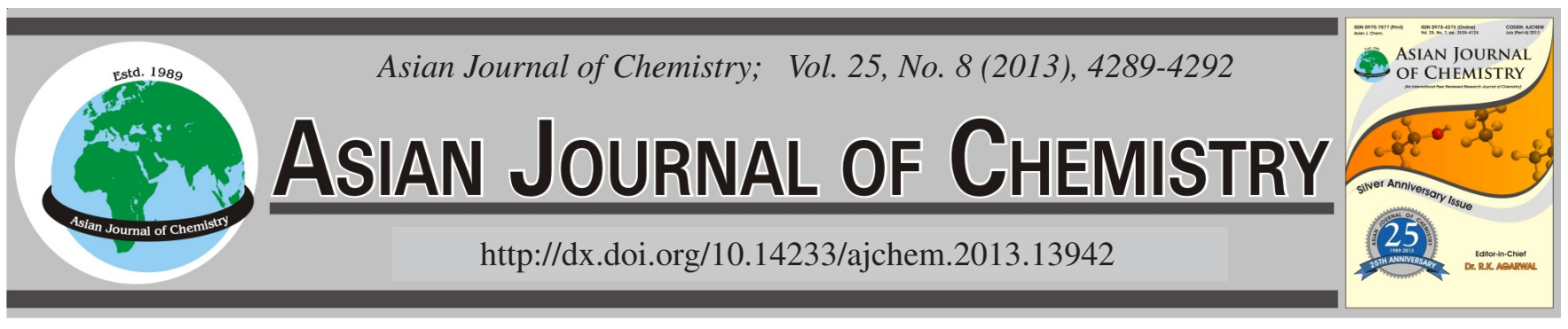

\title{
Synthesis and Structural Characterization of Supramolecular Mn(II)-Li(I) Complex with Salen-Type Bisoxime
}

\author{
Xiu-Yan Dong ${ }^{*}$, Li Wang, Yu-HuA Yang, FA Wang and YuAn Li
}

School of Chemical and Biological Engineering, Lanzhou Jiaotong University, Lanzhou 730070, P.R. China

*Corresponding author: E-mail: dxy568@163.com

\begin{abstract}
Supramolecular manganese(II)-Li(I) complex, $\left[\mathrm{MnL}(\mathrm{OH})\left(\mathrm{H}_{2} \mathrm{O}\right) \mathrm{Li}\right]_{\mathrm{n}}$, has been prepared and characterized by elemental analyses, FTIR, UV-visible spectra, molar conductance measurement and X-ray crystallography (where $\mathrm{H}_{2} \mathrm{~L}=4,4^{\prime}, 6,6^{\prime}$-tetrachloro-2,2'[ethylenedioxybis(nitrilomethylidyne)]diphenol). The complex is self-assembled using various non-covalent interactions including hydrogen bonding interactions and $\pi-\pi$ stacking to form chain supramolecular structure.

Key Words: Salen-type bisoxime, Complex, Synthesis, Crystal structure.
\end{abstract}

\section{INTRODUCTION}

In the past decades, the complexes containing transition metal ions and various Schiff-base ligands have been extensively investigated due to their novel structures and potential applications in many fields ${ }^{1}$. Particularly, a large number of transition metal complexes of Salen-type ligands derived from the condensation of salicylaldehyde and its derivatives with various primary amines become the hot topics of contemporary research $^{2}$. The Salen-type bisoxime ligands have been reported by using an O-alkyloxime unit $\left(-\mathrm{CH}=\mathrm{N}-\mathrm{O}-(\mathrm{CH})_{2}-\mathrm{O}-\mathrm{N}=\mathrm{CH}-\right)$ instead of the $\left(-\mathrm{CH}=\mathrm{N}-(\mathrm{CH})_{2}-\mathrm{N}=\mathrm{CH}-\right)$ group, which can lead to different and novel properties and structures of the resulted complexes $^{3-5}$. but the $\mathrm{Mn}(\mathrm{II})$ complexes with salen-type bisoxime ligands have been reported rarely. In this paper, we report the synthesis, characterization and $\mathrm{X}$-ray crystal structure of the $\mu$-oxo bridged $\left[\mathrm{MnL}^{2}(\mathrm{OH})\left(\mathrm{H}_{2} \mathrm{O}\right) \mathrm{Li}\right]_{\mathrm{n}}$ complex with tetradentate Salen-type bisoxime ligand. The complex is self-assembled using various non-covalent interactions including hydrogen bonding interaction ${ }^{6}$ and $\pi-\pi$ stacking $^{7}$ to form chain supramolecular structure.

\section{EXPERIMENTAL}

3,5-Dichlorosalicylaldehyde was purchased from Alfa Aesar and used without further purification. 1,2-Bis(aminooxy)ethane was synthesized according to an analogous method reported earlier ${ }^{8,9}$. The other reagents and solvents were of analytical reagent grade and were used without further purification. $\mathrm{C}, \mathrm{H}$ and $\mathrm{N}$ analyses were obtained using a $\mathrm{GmbH}$ VarioEL V3.00 automatic elemental analysis instrument. Elemental analyses for Mn and Li were detected by an IRIS
ER/S.WP-1 ICP atomic emission spectrometer. IR spectra were recorded on a VERTEX70 FT-IR spectrophotometer, with samples prepared as $\mathrm{KBr}\left(4000-500 \mathrm{~cm}^{-1}\right)$ and $\mathrm{CsI}(500-100$ $\mathrm{cm}^{-1}$ ) pellets. ${ }^{1} \mathrm{H}$ NMR spectra were determined by German Bruker AVANCE DRX-400 spectroscopy. X-Ray single crystal structure determination was carried out on a Bruker Smart 1000 CCD diffractometer. Molar conductance value measurement was carried out on a model DDS-11D type conductivity bridge using $1.0 \times 10^{-3} \mathrm{~mol} \times \mathrm{dm}^{-3}$ solution in DMF at $18^{\circ} \mathrm{C}$. Melting points were obtained by use of a microscopic melting point apparatus made in Beijing Taike Instrument Limited Company and were uncorrected.

\section{General procedure}

4,4',6,6'-Tetrachloro-2,2'-[ethylenedioxybis(nitrilomethylidyne)]diphenol $\left(\mathbf{H}_{2} \mathbf{L}\right): \mathrm{H}_{2} \mathrm{~L}$ was prepared according to an analogous method reported earlier ${ }^{5,10,11}$. By mixing of 3,5-dichloro-2-hydroxybenzaldehyde $(399.0 \mathrm{mg}, 2.10 \mathrm{mmol})$ and 1,2-bis(aminooxy)ethane (180.1 mg, $1.05 \mathrm{mmol}$ ) in ethanol solution $(8 \mathrm{~mL})$, a pale-yellow solution was obtained. After the solution had been stirred at $55^{\circ} \mathrm{C}$ for $3 \mathrm{~h}$, the mixture was filtered, washed successively with ethanol and hexane, respectively. The product was dried under reduced pressure and purified with recrystallization from ethanol to yield 318.95 mg of colourless crystalline solid. Yield $72.8 \%$. m.p. 204$205^{\circ} \mathrm{C}$. Anal. calcd. (\%) for $\mathrm{C}_{16} \mathrm{H}_{12} \mathrm{~N}_{2} \mathrm{O}_{4} \mathrm{Cl}_{4}$ : C, 43.87; $\mathrm{H}, 2.76$; $\mathrm{N}, 6.39$. Found (\%): C, 43.95; H, 2.68; N, 6.28. ${ }^{1} \mathrm{H}$ NMR (400 $\left.\mathrm{MHz}, \mathrm{DMSO}-d_{6}, \delta, \mathrm{ppm}\right) 4.48\left(\mathrm{~s}, 4 \mathrm{H}, \mathrm{CH}_{2}\right), 7.53(\mathrm{t}, J=2.6$ $\mathrm{Hz}, 2 \mathrm{H}, \mathrm{Ar}-\mathrm{H}), 7.61$ (t, $J=2.6 \mathrm{~Hz}, 2 \mathrm{H}, \mathrm{Ar}-\mathrm{H}), 8.47$ (d, $J=2.0$ $\mathrm{Hz}, 2 \mathrm{H},=\mathrm{C}-\mathrm{H}), 10.38$ (s, 2H, OH). 
$\left[\mathbf{M n L}(\mathbf{O H})\left(\mathbf{H}_{2} \mathbf{O}\right) \mathbf{L i}\right]_{\mathbf{n}}$ : A solution of $\mathrm{Mn}(\mathrm{II})$ acetate tetrahydrate $(12.3 \mathrm{mg}, 0.05 \mathrm{mmol})$ in methanol $(15 \mathrm{~mL})$ was added dropwise to a solution of $\mathrm{H}_{2} \mathrm{~L}(21.9 \mathrm{mg}, 0.05 \mathrm{mmol})$ in THF (45 mL) at room temperature. The colour of the mixing solution turned to yellow immediately. After $10 \mathrm{~min}, \mathrm{LiCl}$ (4.2 $\mathrm{mg}, 0.1 \mathrm{mmol}$ ) dissolved in the minimum amount of water, was poured into the solution. After continuing stirring for 5 days at room temperature, the mixture was filtered and the filtrate was allowed to stand at room temperature for several weeks. Then the solvent partially evaporated and yellow needle-like single crystals suitable for X-ray crystallographic analysis were obtained. Yield: $35.7 \%$. Anal. calcd. (\%) for $\mathrm{C}_{16} \mathrm{H}_{13} \mathrm{Cl}_{4} \mathrm{LiMnN}_{2} \mathrm{O}_{6}\left(\left[\mathrm{MnL}(\mathrm{OH})\left(\mathrm{H}_{2} \mathrm{O}\right) \mathrm{Li}\right]_{\mathrm{n}}\right): \mathrm{C}, 36.12 ; \mathrm{H}, 2.39$; Li, 1.30; Mn, 10.33; N, 5.22. Found (\%): C, 36.11; H, 2.43; Li, 1.31; Mn, 10.29; N, 5.24.

$\mathrm{X}$-Ray structure determination: The crystal data and structure refinement for $\left[\mathrm{MnL}(\mathrm{OH})\left(\mathrm{H}_{2} \mathrm{O}\right) \mathrm{Li}\right]_{\mathrm{n}}$ is given in Table-1. The single crystal of $\left[\mathrm{MnL}(\mathrm{OH})\left(\mathrm{H}_{2} \mathrm{O}\right) \mathrm{Li}\right]_{\mathrm{n}}$ with approximate dimension of $0.40 \mathrm{~mm} \times 0.13 \mathrm{~mm} \times 0.02 \mathrm{~mm}$ were placed on a Bruker Smart 1000 CCD area detector. The diffraction were collected using a graphite monochromated $\mathrm{MoK}_{\alpha}$ radition $(\lambda$ $=0.71073 \AA$ ) at $298(2) \mathrm{K}$. The structure was solved by using the program SHELXL-97 and Fourier difference technique and refined by full-matrix least-square method on $\mathrm{F}^{2}$. All hydrogen atoms were added theoretically.

\begin{tabular}{|c|c|}
\hline \multicolumn{2}{|c|}{$\begin{array}{c}\text { TABLE-1 } \\
\text { CRYSTAL DATA AND STRUCTURE } \\
\text { REFINEMENT FOR THE TITLE COMPLEX }\end{array}$} \\
\hline Empirical formula & $\mathrm{C}_{16} \mathrm{H}_{13} \mathrm{Cl}_{4} \mathrm{LiMnN}_{2} \mathrm{O}_{6}$ \\
\hline Formula weight & 532.96 \\
\hline Temperature & $298(2) \mathrm{K}$ \\
\hline Wavelength & $0.71073 \AA$ \\
\hline Crystal system & Monoclinic \\
\hline Space group & $\mathrm{C} 2 / \mathrm{c}$ \\
\hline Cell dimensions & $\begin{array}{l}\mathrm{a}=17.2609(18) \AA, \mathrm{b}=15.1325(16) \\
\AA, \mathrm{c}=7.7642(9) \AA, \beta=97.1480(10)\end{array}$ \\
\hline Volume & 2012.3(4) $\AA^{3}$ \\
\hline $\mathrm{Z}$ & 4 \\
\hline Density (calculated) & $1.759 \mathrm{mg} / \mathrm{m}^{3}$ \\
\hline Absorption coefficient & $1.225 \mathrm{~mm}^{-1}$ \\
\hline$F_{(000)}$ & 1068 \\
\hline Index ranges & $-20 \leq \mathrm{h} \leq 19,-14 \leq \mathrm{k} \leq 18,-9 \leq 1 \leq 9$ \\
\hline Reflections collected/unique & $5052 / 1762\left[\mathrm{R}_{\text {(int) }}=0.0314\right]$ \\
\hline Independent reflections & 2092 \\
\hline Data/restraints/parameters & $1762 / 0 / 137$ \\
\hline Goodness of fit indicator & 0.981 \\
\hline $\mathrm{R}[\mathrm{I}>2 \sigma(\mathrm{I})]$ & $\mathrm{R}_{1}=0.0441, \mathrm{wR}_{2}=0.1153$ \\
\hline Largest diff. peak and hole & 0.694 and -0.367 e. $\AA$ \\
\hline
\end{tabular}

\section{RESULTS AND DISCUSSION}

Crystal structure of $\left[\mathrm{MnL}(\mathrm{OH})\left(\mathrm{H}_{2} \mathrm{O}\right) \mathrm{Li}\right]_{\mathrm{n}}$ : Interaction of $\mathrm{Mn}(\mathrm{II})$ acetate tetrahydrate with the appropriate Salen-type ligand in a basic medium yields $\left[\mathrm{MnL}(\mathrm{OH})\left(\mathrm{H}_{2} \mathrm{O}\right) \mathrm{Li}\right]_{\mathrm{n}}$ depending on the time of reaction. Suitable single crystals of the complex was obtained by natural evaporation method. X-Ray single crystal determination shows that the complex forms a selfassembling continual supramolecular structure by hydrogen bonding interactions and $\pi-\pi$ stacking. The atom numbering and the chain supramolecular structure of the complex is given in Fig. 1. Selected bond distances and angles of the complex are listed in Table-2.

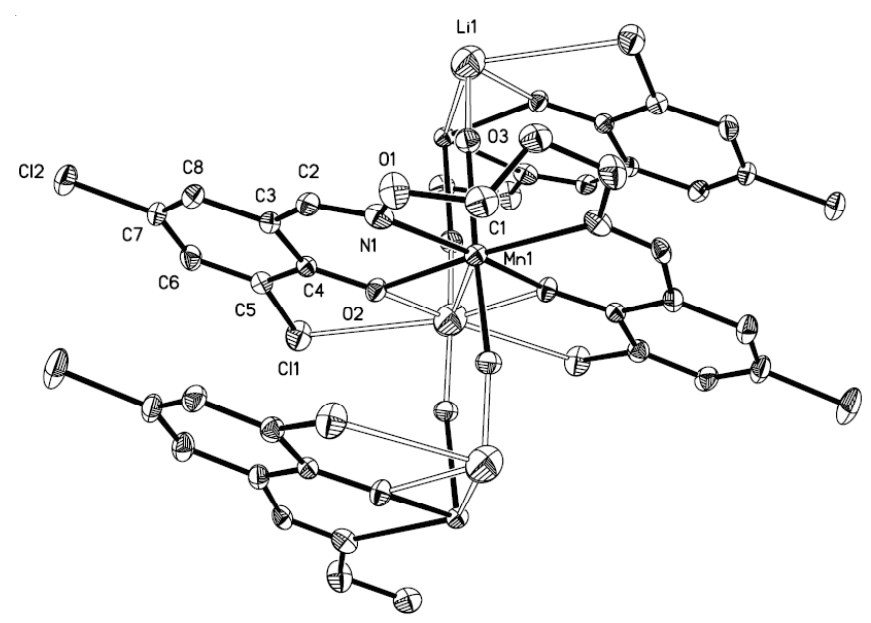

Fig. 1. Molecule structure of the title complex with atom numbering scheme. Displacement ellipsoids for non-hydrogen atoms are drawn at the $30 \%$ probability level

The complex has been synthesized from the reaction of the ligand $\left(\mathrm{H}_{2} \mathrm{~L}\right), \mathrm{Mn}(\mathrm{II})$ acetate tetrahydrate and $\mathrm{LiCl}$ in mixing solution and revealed by X-ray crystallography. The complex is crystallized in the monoclinic system, space group $\mathrm{C} 2 / \mathrm{c}$. The structural of $\left[\mathrm{MnL}^{2}(\mathrm{OH})\left(\mathrm{H}_{2} \mathrm{O}\right) \mathrm{Li}\right]_{\mathrm{n}}$ adopts a slightly distorted octahedral geometry with a hexa-coordinated $\mathrm{Mn}$ (II) center. $\mathrm{L}^{2-}$ unit behaves as a tetradentate agent via two phenolic oxygen and two oxime nitrogen atoms, which are in the equatorial positions. The Mn-O (phenolic) bond of 2.122(2) $\AA$ and Mn-N(oxime) bond of 2.307(3) $\AA$ are in agreement with the average bond lengths seen for the corresponding bonds in the $\mathrm{Mn}$ (II) complexes bearing tetradentate salen-type ligands in a planar fashion ${ }^{12}$. The four $\mathrm{N}_{2} \mathrm{O}_{2}$ donor atoms of $\mathrm{L}^{2-}$ unit are approximately coplanar and the dihedral angle of O2-Mn1$\mathrm{N} 1$ and ${ }^{2}{ }^{\mathrm{i}}-\mathrm{Mn} 1-\mathrm{N} 1^{\mathrm{i}}$ is $2.08^{\circ}$. The axial sites of $\mathrm{Mn}$ (II) atom is occupied by two oxygen atoms of one coordinated water molecule and one hydroxy group in a considerably large angle of O3-Mn1-O3 $3^{\mathrm{i}}\left(167.63(14)^{\circ}\right)$. It is noticeably that the bond distance Mn1-O3 (2.152(3) $\AA$ ) is the same with Mn1-O3 ${ }^{\mathrm{i}}$, which indicate the same coordination abilities of the two $\mu$-oxo bridges.

In addition, every monomer of the complex contains a $\mathrm{Li}(\mathrm{I})$ atom. The coordination geometry around the $\mathrm{Li}(\mathrm{I})$ (Li1) atom can be best described as slightly distorted square pyramidal geometry with unexpected penta-coordinated. Two phenolic oxygen atoms $\left(\mathrm{O} 2^{\mathrm{ii}}\right.$ and $\left.\mathrm{O} 2^{\mathrm{iv}}\right)$ and two chlorine $\left(\mathrm{Cl} 1^{\mathrm{ii}}\right.$ and $\mathrm{Cl}^{1 \text { iv }}$ atoms of $\mathrm{L}^{2-}$ unit constitute the basal plane and one oxygen atoms from the bridging hydroxy group in the axial position. The distance of $\mathrm{Mn} 1 \cdots \operatorname{Li} 1^{\mathrm{ii}}(2.800(15) \AA)$ is significantly longer than all the $\mathrm{Mn}-\mathrm{O}$ and $\mathrm{Mn}-\mathrm{N}$ bonds in the complex, indicating a weaker intermetal interaction. The complex has four intermolecular hydrogen bonds $(\mathrm{O} 3-\mathrm{H} 3 \mathrm{~A} \cdots \mathrm{O} 2, \mathrm{O} 3-$ $\mathrm{H} 3 \mathrm{~B} \cdots \mathrm{O} 2, \mathrm{O} 3-\mathrm{H} 3 \mathrm{~A} \cdots \mathrm{Cl} 1$ and $\mathrm{O} 3-\mathrm{H} 3 \mathrm{~B} \cdots \mathrm{Cl} 1)$ which help to connect the individual monomer to form and stabilize the threedimensional structure (Table-3). The special interest of the complex is its self-assembling $\mathrm{Mn}(\mathrm{II})-\mathrm{O}-\mathrm{Li}(\mathrm{I})$ chain array stacked by hydrogen bonding interactions and $\pi-\pi$ stacking of 
TABLE-2

SELECTED BOND DISTANCES $(\AA)$ AND ANGLES $\left({ }^{\circ}\right)$ FOR THE TITLE COMPLEX

\begin{tabular}{|c|c|c|c|c|c|}
\hline Bond & Lengths & Bond & Lengths & Bond & Lengths \\
\hline $\mathrm{Mn} 1-\mathrm{O} 2$ & $2.122(2)$ & $\mathrm{Mn} 1-\mathrm{N} 1^{\mathrm{i}}$ & $2.307(3)$ & $\mathrm{Li} 1-\mathrm{O} 2^{\text {iv }}$ & $2.058(10)$ \\
\hline $\mathrm{Mn} 1-\mathrm{O} 2^{\mathrm{i}}$ & $2.122(2)$ & Mn1-N1 & $2.307(3)$ & $\mathrm{Li} 1-\mathrm{O} 2^{\mathrm{ii}}$ & $2.058(10)$ \\
\hline $\mathrm{Mn} 1-\mathrm{O} 3^{\mathrm{i}}$ & $2.152(3)$ & Mn1-Li1 $1^{\mathrm{ii}}$ & $2.800(15)$ & $\mathrm{Li} 1-\mathrm{Cl}^{\mathrm{iv}}$ & $3.003(7)$ \\
\hline Mn1-O3 & $2.152(3)$ & $\mathrm{Li1}^{-\mathrm{O}}{ }^{\mathrm{iii}}$ & $1.761(3)$ & $\mathrm{Li}_{1-\mathrm{Cl}} 1^{\mathrm{ii}}$ & $3.003(7)$ \\
\hline Bond & Angles & Bond & Angles & Bond & Angles \\
\hline $\mathrm{C}(10)-\mathrm{N}(1)-\mathrm{O}(1)$ & $113.3(5)$ & $\mathrm{C}(11)-\mathrm{C}(12)-\mathrm{C}(13)$ & $116.9(6)$ & $\mathrm{O}(4)-\mathrm{C}(23)-\mathrm{C}(24)$ & $121.9(6)$ \\
\hline $\mathrm{O} 2-\mathrm{Mn} 1-\mathrm{O} 2^{\mathrm{i}}$ & $93.96(13)$ & $\mathrm{N} 1{ }^{\mathrm{i}}-\mathrm{Mn} 1-\mathrm{N} 1$ & $106.84(16)$ & O3-Mn1-Li1 $1^{\mathrm{ii}}$ & $96.18(7)$ \\
\hline $\mathrm{O} 2-\mathrm{Mn} 1-\mathrm{O} 3$ & $94.07(10)$ & O2-Mn1-Li $1^{\mathrm{ii}}$ & $46.98(6)$ & Li1-O3-Mn1 & $165.4(5)$ \\
\hline $\mathrm{O} 33^{\mathrm{i}}-\mathrm{Mn} 1-\mathrm{O} 3$ & 167.63(14) & N1-Mn1-Li1 $1^{\mathrm{ii}}$ & $126.58(8)$ & $\mathrm{O} 2^{\mathrm{ii}}-\mathrm{Li} 1-\mathrm{Cl} 1^{\mathrm{ii}}$ & $68.11(9)$ \\
\hline O2-Mn1-N1 & $79.61(10)$ & O3-Mn1-N1 & $84.78(11)$ & $\mathrm{Cl} 1^{\mathrm{iv}}-\mathrm{Li} 1-\mathrm{Cl} 1^{\mathrm{ii}}$ & $126.4(5)$ \\
\hline
\end{tabular}

Symmetry transformations used to generate equivalent atoms: (i) $-\mathrm{x}+1, \mathrm{y},-\mathrm{z}+1 / 2$ (ii) $-\mathrm{x}+1,-\mathrm{y}+1,-\mathrm{z}$ (iii) $-\mathrm{x}+1, \mathrm{y},-\mathrm{z}-1 / 2$ (iv) $\mathrm{x},-\mathrm{y}+1, \mathrm{z}-1 / 2$.

TABLE-3

HYDROGEN BONDS $\left[\AA \AA^{\circ}\right]$ FOR THE TITLE COMPLEX

\begin{tabular}{|c|c|c|c|c|c|}
\hline $\mathrm{D}-\mathrm{H} \cdots \mathrm{A}$ & $\mathrm{d}(\mathrm{D}-\mathrm{H})$ & $\mathrm{d}(\mathrm{H} \cdots \mathrm{A})$ & $\mathrm{d}(\mathrm{D} \cdots \mathrm{A})$ & $\angle \mathrm{DHA}$ & Symmetry \\
\hline $\mathrm{O} 3-\mathrm{H} 3 \mathrm{~A} \cdots \mathrm{O} 2$ & 0.85 & 2.18 & $2.913(3)$ & 144 & $-\mathrm{x}+1,-\mathrm{y}+1,-\mathrm{z}$ \\
\hline 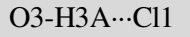 & 0.85 & 2.79 & $3.393(3)$ & 129 & $-x+1,-y+1,-z$ \\
\hline $\mathrm{O} 3-\mathrm{H} 3 \mathrm{~B} \cdots \mathrm{O} 2$ & 0.85 & 1.93 & $2.714(3)$ & 153 & $\mathrm{x},-\mathrm{y}+1, \mathrm{z}-1 / 2$ \\
\hline O3-H3B $\cdots \mathrm{Cl} 1$ & 0.85 & 2.89 & $3.398(3)$ & 120 & $\mathrm{x},-\mathrm{y}+1, \mathrm{z}-1 / 2$ \\
\hline
\end{tabular}

neighboring benzene rings (Fig. 2). Two neighboring monomers have the anti-conformation, the angle of the two neighboring benzene rings is $0.87(3)^{\circ}$ and the mean distance between the two neighboring benzene rings is $3.638 \AA$, indicating weak $\pi-\pi$ stacking interaction.

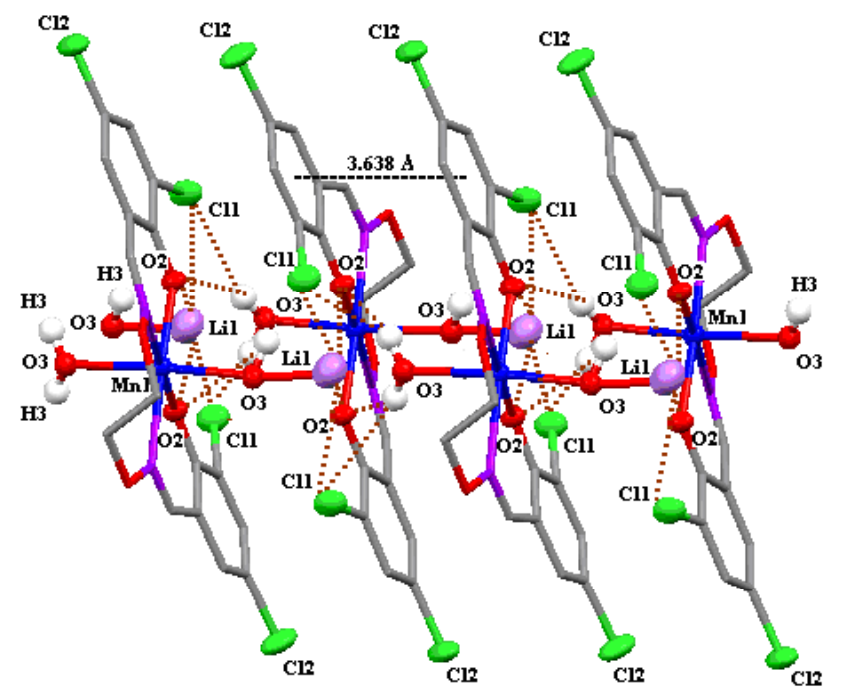

Fig. 2. View of the $1 \mathrm{D}$ chain supramolecular structure of Mn(II)-Li complex along the a axis (hydrogen atoms, except those forming hydrogen bonds, are omitted for clarity)

Molar conductance: Molar conductance values of the complex at $18^{\circ} \mathrm{C}$ of $10^{-3} \mathrm{~mol} \times \mathrm{dm}^{-3} \mathrm{DMF}$ solution is $7.6 \mathrm{~S} \times$ $\mathrm{cm}^{2} \times \mathrm{mol}^{-1}$, indicating that the complex is non-electrolyte. This implies that all the $\mathrm{Mn}(\mathrm{II})$ and $\mathrm{Li}(\mathrm{I})$ atoms in the complex are firmly held in the coordination sphere in solution.

IR spectra: The main characteristic infrared spectral bands of the free ligand and its $\mathrm{Mn}(\mathrm{II})-\mathrm{Li}(\mathrm{II})$ complex are shown in Table-4. IR spectrum of $\mathrm{H}_{2} \mathrm{~L}$ exhibits characteristic $\mathrm{C}=\mathrm{N}_{\text {oxime }}$ stretching band at $1609 \mathrm{~cm}^{-1}$, while the $\mathrm{C}=\mathrm{N}_{\text {oxime }}$ of the complex was observed at $1603 \mathrm{~cm}^{-1}$. The $\mathrm{C}=\mathrm{N}_{\text {oxime }}$ band is shifted

\begin{tabular}{lccccc}
\multicolumn{5}{c}{ TABLE-4 } \\
\multicolumn{5}{c}{ KEY IR BANDS FOR THE LIGAND } \\
AND THE TITLE COMPLEX $\left(\mathrm{cm}^{-1}\right)$ \\
\hline Compound & $v(\mathrm{O}-\mathrm{H})$ & $v\left(\mathrm{CH}_{\text {arom }}\right)$ & $v\left(\mathrm{CH}_{2}\right)$ & $v(\mathrm{C}=\mathrm{N})$ & $v(\mathrm{C}-\mathrm{O})$ \\
\hline $\mathrm{H}_{2} \mathrm{~L}$ & 3427 & 3078 & 2963,2899 & 1609 & 1277 \\
Complex & 3414 & 3079 & 2955,2891 & 1603 & 1304 \\
\hline
\end{tabular}

to lower frequency by $c a .6 \mathrm{~cm}^{-1}$ upon complexation. At the same time, $\mathrm{C}-\mathrm{O}_{\text {phenol }}$ stretching frequency appears as a strong band in the compound. This band occurs at $1277 \mathrm{~cm}^{-1}$ for $\mathrm{H}_{2} \mathrm{~L}$ and at $1304 \mathrm{~cm}^{-1}$ for the complex. The $\mathrm{C}-\mathrm{O}_{\text {phenol }}$ stretching band is shifted to higher frequency by $27 \mathrm{~cm}^{-1}$ upon complexation. These data suggest the coordination of the ligand in their dianionic form to the $\mathrm{Mn}$ (II) atom through the phenol oxygen and the oxime nitrogen atoms and show the tetradentate character of the ligand in the complex ${ }^{13-15}$. Additionally, strong and broad bands at $3414 \mathrm{~cm}^{-1}$ indicates that $\mathrm{O}-\mathrm{H}$ is existent in the complex.

The far-infrared spectrum of the complex is also obtained in the region $500-100 \mathrm{~cm}^{-1}$ in order to identify frequencies due to the $v(\mathrm{Mn}-\mathrm{O})$ and $v(\mathrm{Mn}-\mathrm{N})$ bonds. IR spectrum of the complex shows $v(\mathrm{Mn}-\mathrm{N})$ and $v(\mathrm{Mn}-\mathrm{O})$ vibrational absorption frequencies at 473 and $448 \mathrm{~cm}^{-1}$, respectively, which are consistent with the literature frequency values ${ }^{16}$. These bands are observed as new peaks for the complex are not present in the spectrum of the free ligand.

UV-visible absorption spectra: The UV-visible absorption spectra of the ligand $\mathrm{H}_{2} \mathrm{~L}$ and its corresponding complex in diluted DMF solution are shown in Fig. 3. It can be seen that the absorption peaks of the complex are obviously different from those of the free ligand upon complexation. Compared with the complex, an important feature of the absorption spectrum of $\mathrm{H}_{2} \mathrm{~L}$ is shown that one absorption peak is observed at $324 \mathrm{~nm}$, which is absent in the spectrum of the complex. The other feature is that the absorption peak at $268 \mathrm{~nm}$ in $\mathrm{H}_{2} \mathrm{~L}$ is shifted to $266 \mathrm{~nm}$ in the complex and a new absorption peak at $377 \mathrm{~nm}$ was observed in the complex, indicating that the coordination of $\mathrm{Mn}(\mathrm{II})$ atom with $\mathrm{H}_{2} \mathrm{~L}$. 


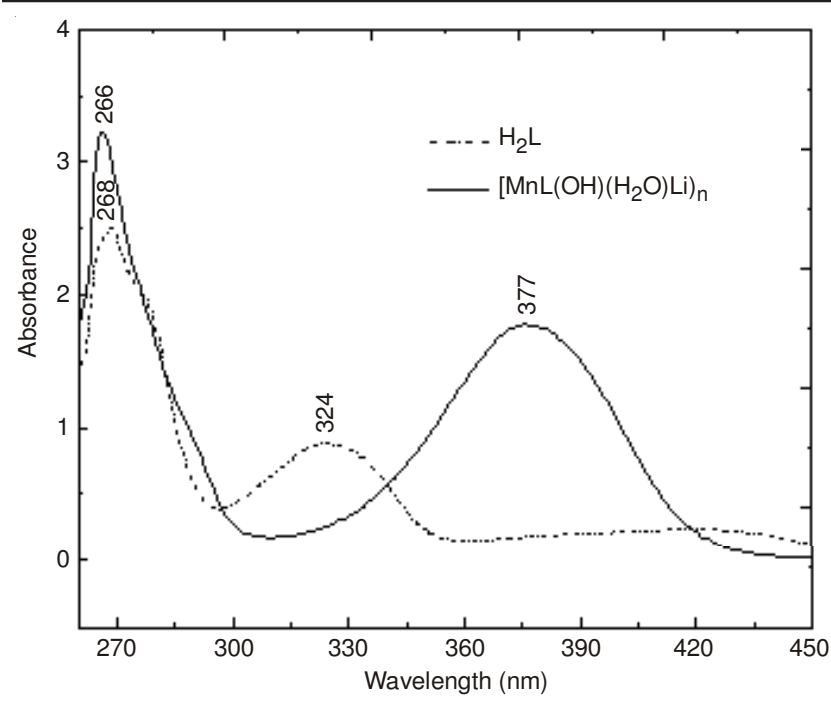

Fig. 3. UV-visible absorption spectra of $\mathrm{H}_{2} \mathrm{~L}(-\cdot-\cdot)$ and the title complex $(-)$ in DMF $\left(1.0 \times 10^{-4} \mathrm{~mol} / \mathrm{L}\right)$

\section{Conclusion}

According to the data and discussion above, the new complex, $\left[\mathrm{MnL}(\mathrm{OH})\left(\mathrm{H}_{2} \mathrm{O}\right) \mathrm{Li}\right]_{\mathrm{n}}$, has been synthesized and structurally characterized. In FT-IR spectra of the complex, the $v(\mathrm{M}-\mathrm{O})$ and $v(\mathrm{M}-\mathrm{N})$ vibrational absorption frequencies have been observed. The structure of the complex has been determined by X-ray diffraction technique, The complex forms a one-dimensional infinite self-assembling chain supramolecular structure by hydrogen bonding interactions and $\pi-\pi$ stacking of neighbouring benzene rings.

Supplement data: Further details of the crystal structure investigation(s) may be obtained from the Cambridge Crystallographic Data Centre, Postal Address: CCDC, 12 Union Road, CAMBRIDGE CB2 1EZ, UK. Telephone: (44) 01223 762910; Facsimile: (44) 01223 336033; E-mail: deposit@ccdc.cam.ac.uk, on quoting the depository number CCDC 712160

\section{ACKNOWLEDGEMENTS}

The authors acknowledged the finanical support from 'Jing Lan' Talent Engineering Funds of Lanzhou Jiaotong University.

\section{REFERENCES}

1. W.K. Dong, G. Wang, S.S. Gong, J.F. Tong, Y.X. Sun and X.H. Gao, Transition Met. Chem., 37, 271 (2012).

2. A.K. Sah, T. Tanase and M. Mikuriya. Inorg. Chem., 45, 2083 (2006).

3. W.K. Dong, C.E. Zhu, H.L.Wu, Y.J. Ding and T.Z. Yu, Synth. React. Inorg. Met.-Org. Nano-Met. Chem., 37, 61 (2007).

4. W.K. Dong, J.G. Duan, L.Q. Chai, J.Y. Shi, G.L.Liu and H.L. Wu, J. Coord. Chem., 61, 1306 (2008).

5. W.K. Dong, J.Y. Shi, L. Xu, J.K. Zhong, J.G. Duan and Y.P. Zhang, Appl. Organomet. Chem., 22, 89 (2008).

6. M. Suzuki, T. Sato, A. Kurose, H. Shirai and K. Hanabusa, Tetrahedron Lett., 46, 2741 (2005).

7. S.J. George, A. Ajayaghosh, P. Jonkheijm, A.P.H.J. Scheening and E.W. Meijer, Angew. Chem. Int. Ed., 43, 3421 (2004).

8. W.K. Dong, L. Li, C.F. Li, L. Xu and J.G. Duan, Spectrochim. Acta A, 71, 650 (2008).

9. W.K. Dong, Y.X. Sun, Y.P. Zhang, L. Li, X.N. He and X.L. Tang, Inorg. Chim. Acta, 362, 117 (2009).

10. W.K. Dong, C.Y. Zhao, Y.X. Sun, X.L. Tang and X.N. He, Inorg. Chem. Commun., 12, 234 (2009).

11. P.K. Saha, B. Dutta, S. Jana, R. Bera, S. Saha, K. Okamoto and S. Koner, Polyhedron, 26, 563 (2007).

12. A. Panja, N. Shaikh, P. Vojtišek, S. Gao and P. Banerjee, New J. Chem., 26, 1025 (2002).

13. A. Anthonysamy and S. Balasubramanian, Inorg. Chem. Commun., 8, 908 (2005).

14. W.K. Dong, X.N. He, H.B. Yan, Z.W. Lv, X. Chen, C.Y. Zhao and X.L. Tang, Polyhedron, 28, 1419 (2009).

15. W.K. Dong, J.G. Duan, Y.H. Guan, J.Y. Shi and C.Y. Zhao, Inorg. Chim. Acta, 362, 1129 (2009).

16. J. Chakraborty, B. Samanta, G. Pilet and S. Mitra, Struct. Chem., 17, 585 (2006). 